\title{
ANALYSIS OF BUILDING SYSTEMS AND TECHNOLOGICAL CHARACTERIZATION OF MEDIEVAL SHIPYARD
}

\author{
ANTONELLO PAGLIUCA \& DOMENICO DEBENEDICTIS \\ Università degli Studi della Basilicata, Matera, Italia.
}

\begin{abstract}
Shipyards, an architectural typology developed since the classical civilizations to build military or merchant vessels, found their greatest technological progress in the Middle Ages. Especially in the Mediterranean area, they were built with different techniques and materials, generating different characteristics related to the context in which they were grown. These architectures, which are examples of prosperous times for the medieval harbour towns, seemed obsolete a few decades ago regarding the original functions for which they were built. Today, they are partly in an evident degradation state and partly recovered. In a contemporary logic that provides for the reuse of places, by the characteristic industrial feature now disused, in new cultural centres and attractive poles for these cities, the constructive conformation as well as technologies and materials applied should be understood. Some of the most influential medieval dockyards in the Mediterranean basin were analyzed, considering the places in which they are based and the main constructive elements, with particular attention paid to the analysis of representative technological systems of the whole structure (i.e. piers, pillars and arcs; old wooden roofing systems; stone vaulted structures). The study aims to develop a comparative analysis in terms of morphology, materials and construction techniques of the elements that configure the aisles or lanes in which different boats were built, repaired or preserved or stored. The aim is to demonstrate that, despite the peculiarities of each site, in which the traditional building techniques linked to local materials were used, the medieval shipyard architectural type have evolved and consolidated in a homologous way in the whole Mediterranean area.

Keywords: Mediterranean basin, middle ages, shipyard, typo-technological analysis.
\end{abstract}

\section{INTRODUCTION}

The research on historical dockyards, both in Italy and abroad, is currently based purely on the historical and archaeological points of view, based on classical examples (Hellenistic neoria and Roman navalia), and studied through archaeological excavations. The shipyards found their significant typological progress in the Middle Ages, the period in which the architecture began to experiment with new construction techniques that allowed creation of more articulate shapes and consistent spaces, too. These new architecture techniques, originally used for building worship places, were promptly transferred to civilian facilities, and then to military structures (i.e. the arsenals that allowed keeping and/or making greater and greater vessels).

This drove the great naval powers, such as the Maritime Republics in the Mediterranean, to build new port facilities of strategic importance from the military-political, but also social and economic, aspects.

Today, these huge monuments are embedded within the fabric of ancient cities [1].

Although medieval arsenals are infrastructures of major influence in the Mediterranean basin, their recovery has not been addressed until now. The study and knowledge of these places have been performed mostly by historians and archaeologists, who so far have rather analyzed the relationship with the port, the trade routes and their impact on military development, focussing mainly on the activities that actually were held inside the yards: construction of boats and their crew, composition of cordage, sails and anchoring elements, as well as the 
production of artillery. Today, we know enough about naval engineering, about the art of producing boats and the technologies used, but attention has not been given to the building sites in which they came to life. Those structures not only had to contain several mini-workshops, but also to preserve and repair all types of vessels.

In fact, these yards need to have large spaces capable of holding in their turn of more or less large construction sites for building boats, arsenals, stores or warehouses, workshops, which were held as a parallel activity, and production units of sheets for sails, ropes and armaments.

Especially in the Middle Ages, within the discovery of America, Europe (particularly in the Mediterranean basin) saw a substantial growth and development of these port infrastructures, which allowed several powers, both in military and commercial fields, to be able to extend their borders. Therefore, they spent enormous energies to fully know, design and build vessels more and more advanced and able to reach unexplored lands, and innovative and impressive spaces such as the arsenals to construct them.

\section{FROM 'NEORIA' AND 'NAVALIA' UP TO MEDIEVAL ARSENALS}

The architectural typology of the arsenal comes from the need to have a sheltered, dry and cool place suitable for the construction, repair, maintenance and custody of all those items and equipment relating to the naval art. In all civilizations with urban settlements near coastal areas, to facilitate maritime trade and especially for military needs, it develops this kind of architecture.

It is supposed that the first arsenals were constituted by a wooden structure, composed essentially of high piers, whole logs of wood, arranged in parallel rows with the function of holding a slightly sloped roof or in a double pitch, such as those of Samo [2] in Greece.

The real original type of naval arsenal can be considered, according to archaeological historical sources, that of neoria of Greek civilization. The neoria, literally 'the place where there is taken care of ships' [3], was a structure that was used merely to preserve and protect the boats, particularly during the winter or in wartime truces periods. It was in the next external zones of these, however, in which they took shape and worked hulls. In the Periclean era, it developed the so-called Neoria, which were long rows of stone columns, placed in parallel, on which was placed wooden covers that remember to the trusses used to cover the temples. In fact, these buildings could be treated as a series of many temples, when placed side by side, in which, the structural elements were not finished without decoration. These architectures were essentially functional, reflecting the pragmatic character of Greek civilization which wished for colonize new territories and expand trade routes.

The colonnades of neoria often followed the slope of the coast to facilitate the launching operations, the entrance or exit of the boats; it foresaw a continuous rear wall perpendicular to these colonnades, which served as the closing, while the front facing to the sea it was kept open. As regards the cover system, some researches highlight that this is constituted by a double-pitch roof truss that rests on three rows of columns (Fig. 1a), covering two cells, while others consider that the rows of columns were alternated by highest rows and lower rows on which were placed a single pitch (Fig. 1b).

A typology variation, documented and never realized, which comes to the arsenals of Carthage (Fig. 2), was constituted from two adjacent basins, both excavated: the first one, rectangular, which communicated with the sea was reserved to trade; the second one, behind the first, was circular and had an island in the middle, where the headquarters of the admiralty was located. This circular ring was the military port around which were the neoria for accommodating ships, including a higher level used as warehouses. 

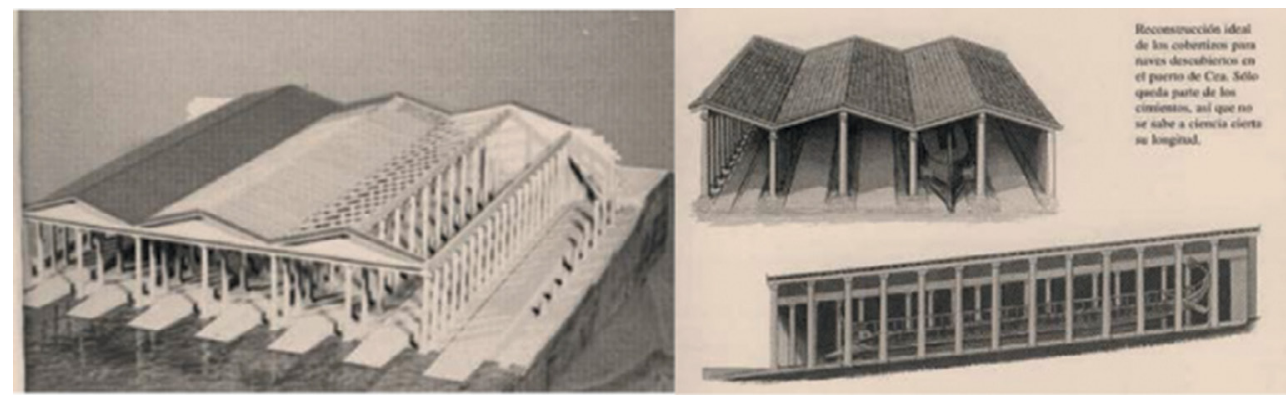

Figure 1: 1a Models of the two reconstruction hypotheses of Zea's 'neoria', 1a (C.T. Panagos, 1968; Greek Nautical Museum, 1984), 1b (La ciudad antigua. La vida en la Atenas y Roma clásicas. P. Conolly, H. Dodge. Acento Editorial, 1998).

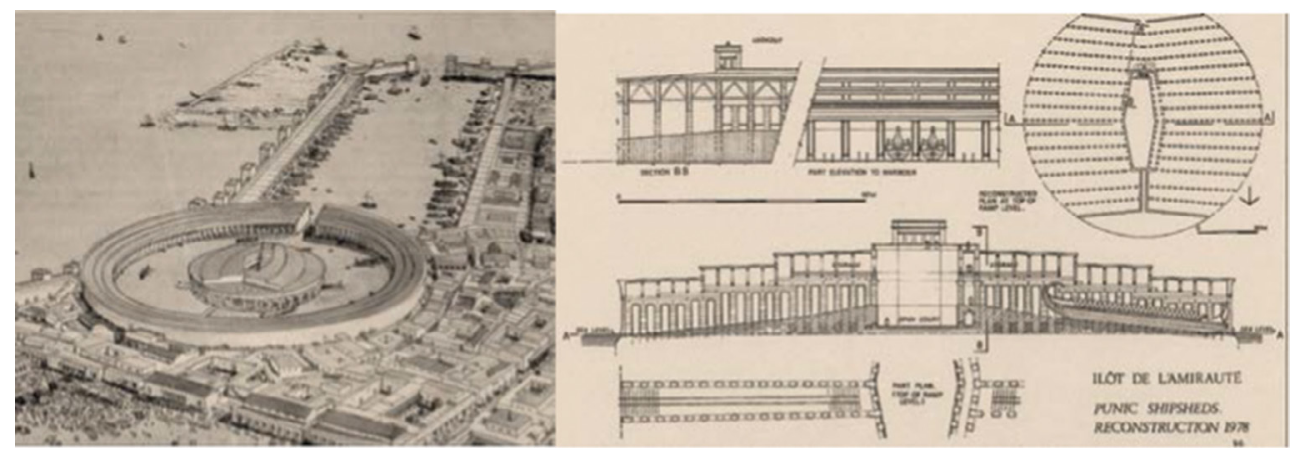

Figure 2: Hypothetical representation of the Hellenistic Carthage port and Reconstruction of the inner harbor.

The Romans refer to the arsenals with the Latin word navalia; in the typological structure, there are no substantial deviations from the Greek; the only change is the use of stone elements (vaulted structures) for the covers, instead the wood. A refinement of the construction system linked to safety reasons in case of possible fires, often caused by the processing of the wood of the boats.

Those different building experimentations led to the medieval arsenal. The etymology of the word comes from the arabic dār aș-șinā 'ah, consisting of $d \bar{a} r$ (house) e aṣ-șinā' ah (art or manufacturing), to precisely indicate a building complex where operations of processing and manufacturing related to art shipbuilding were taking place. The word has been declining according to region, arsenà in Venece, terzana in Pisa, atarazanas in Castilian, dàrsarsenale in Genovese, these are some of the different ways to call these places in medieval times and which still remain [4].

The structure of the medieval shipyards essentially repeats that of the Greek neoria and Roman navalia, providing a series of flanked aisles, near the sea or, more often, a artificial basin (wet dock). The aspect that sets them apart from the classic is the choice of materials and the most advanced technological systems that allowed to give special conformations structures, closely related to technical and technological advancement of naval engineering. 


\section{TYPOLOGICAL CHARACTERIZATION OF MEDIEVAL ARSENALS IN THE MEDITERRANEAN BASIN}

Usually, in architecture, the man creates and shapes the space determining measures and proportions by referring to himself (from the 'Modulor' to anthropometry). In some cases, however, still remaining the proportions with humans, there are other factors which determine the proportion of a space, often linked to human activities, such as spaces for the remittance and the construction of boats.

Humans edify buildings according to their proportions, but dockyards have to be built according to ships' size. So, this observation requires a superior level of proportion. Dockyards, buildings with impressive spatial definition, are created using more complex construction techniques.

Located along the perimeter of the Mediterranean basin for its strong commercial characteristic are numerous arsenals that were developed in medieval times; among them, the most emblematic, given the development of the city in connection with the port, is, good to mention those Italian, Amalfi (Fig. 3) and Pisa (Fig. 4), and the Spanish, Barcelona (Fig. 5) and Seville (Fig. 6). Through the study and the type-technological analysis of these four symbols of the ancient port powers, it is possible to delineate the architectural and technological features that characterize them; characters that for some aspects unite them, for other differentiate them.
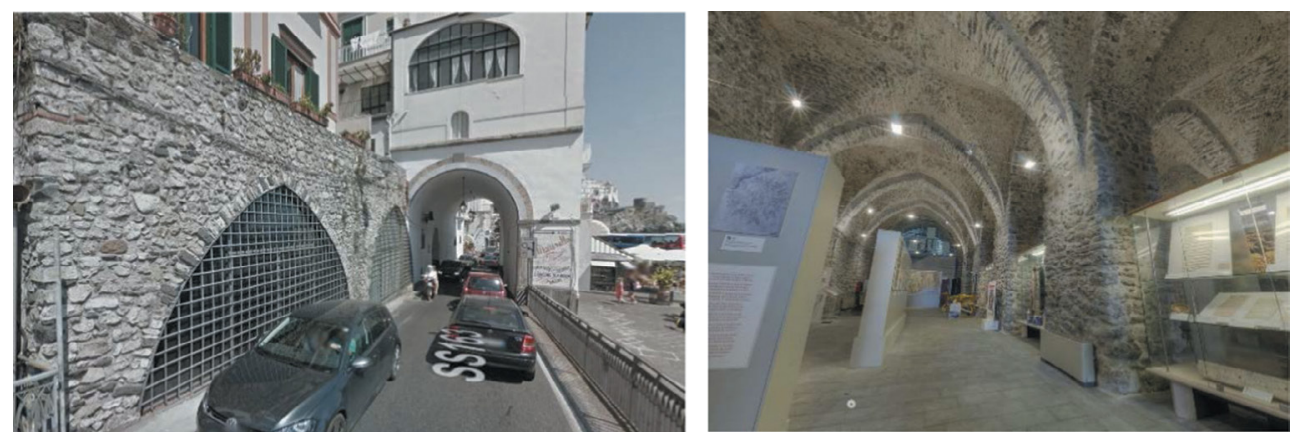

Figure 3: Arsenal of Amalfi.
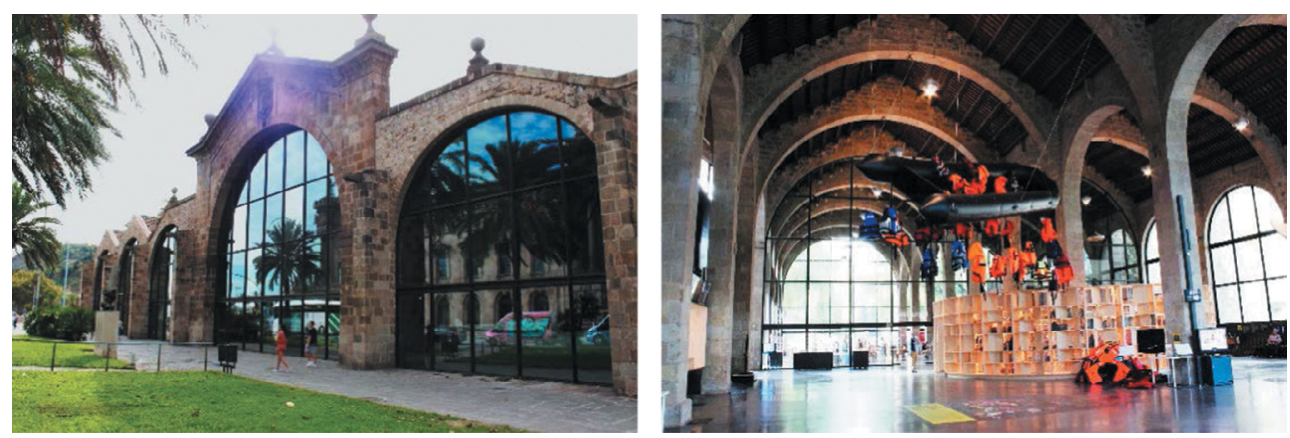

Figure 4: Reales Atarazanas of Barcelona. 

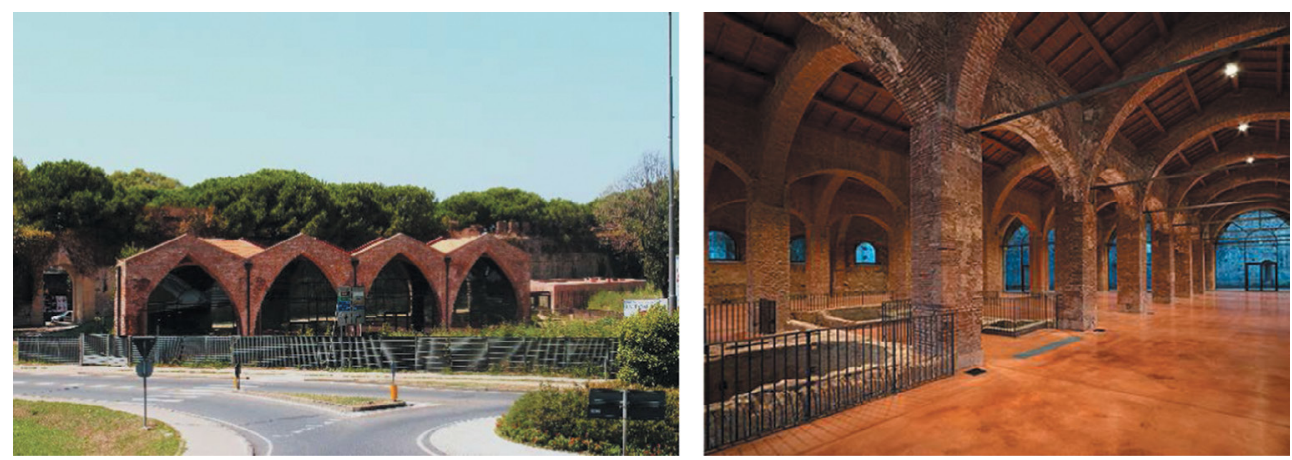

Figure 5: Arsenalof Pisa.
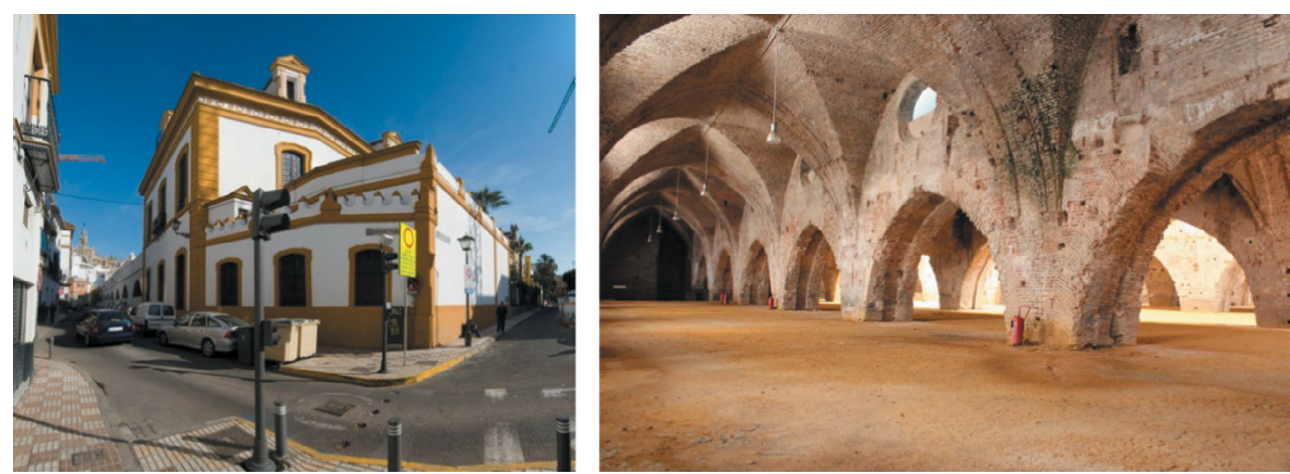

Figure 6: Atarazanas of Seville.

Depending on whether the city is located along a waterway or directly on the Mediterranean coast, the arsenals can be divided into (see Table 1):

- Fluvial, and of course it is navigable rivers, is the case of Pisa over the Arno River and Seville along the Guadalquivir;

- Maritime, such as Barcelona on the Balearic Sea and Amalfi on the Tyrrhenian Sea.

The choice of location is also the determining factor in the choice of materials and construction techniques to be used for the construction of the structure of the arsenals. It employs, in fact, available raw materials in the surrounding areas, prosperous parts of clay for the production of bricks or natural stone materials with high structural features that permit the construction of high-quality masonry.

However, despite the structures were increasingly responsive to functional needs of the construction site, they could only accommodate ships' hulls, providing for mounting of the masts, and their sails, only when they were already in the water. In fact, the limited dimensions in height of the shipbuilding spaces, due precisely to the technological systems not yet advanced, did not allow the realization of these spaces to contain a vessel mounted. 
Table 1: Typological classification.

\begin{tabular}{|c|c|c|c|c|}
\hline & Amalfi & Barcelona & Pisa & Seville \\
\hline Typology & $\begin{array}{l}\text { Maritime arsenals, } \\
\text { perpendicular to } \\
\text { the coast line, con- } \\
\text { structed in contact } \\
\text { with the water }\end{array}$ & $\begin{array}{l}\text { Maritime arse- } \\
\text { nals, perpen- } \\
\text { dicular to the } \\
\text { coastline, built } \\
\text { on the arenile }\end{array}$ & $\begin{array}{l}\text { Fluvial arsenals, } \\
\text { built on wet } \\
\text { dock }\end{array}$ & $\begin{array}{l}\text { Fluvial arse- } \\
\text { nals, perpen- } \\
\text { dicular to } \\
\text { the coastline, } \\
\text { built on the } \\
\text { arenile }\end{array}$ \\
\hline Location & $\begin{array}{l}\text { Placed near the } \\
\text { Tyrrhenian coast, } \\
\text { their location was } \\
\text { on the western side } \\
\text { of the lower town }\end{array}$ & $\begin{array}{l}\text { On the sea side } \\
\text { of the Balearic } \\
\text { Sea, the western } \\
\text { sector of the } \\
\text { beach }\end{array}$ & $\begin{array}{l}\text { Western area of } \\
\text { the city, north of } \\
\text { the River Arno }\end{array}$ & $\begin{array}{l}\text { Arenal area } \\
\text { on the east } \\
\text { coast of } \\
\text { the river } \\
\text { Guadalquivir }\end{array}$ \\
\hline $\begin{array}{l}\text { Original } \\
\text { name }\end{array}$ & Arsenale of Amalfi & $\begin{array}{l}\text { In the early } \\
\text { documents it } \\
\text { is called by } \\
\text { the name of } \\
\text { Arazana. Then } \\
\text { in Catalan, } \\
\text { Drassanes Reials } \\
\text { de Barcelona } \\
\text { (in Spanish } \\
\text { Atrarazanas } \\
\text { Reales de } \\
\text { Barcelona) }\end{array}$ & $\begin{array}{l}\text { Arsenale della } \\
\text { Repubblica } \\
\text { di Pisa or La } \\
\text { Tersana di Pisa, } \\
\text { place called by } \\
\text { the Pisans with } \\
\text { the name of } \\
\text { Cittadella, with } \\
\text { reference to the } \\
\text { fortress function }\end{array}$ & $\begin{array}{l}\text { Reales } \\
\text { Atarazanas } \\
\text { de Sevilla }\end{array}$ \\
\hline
\end{tabular}

\section{TYPOLOGICAL CHARACTERIZATION OF ARSENALS}

The usable space to accommodate and protect a vessel is defined by a rectangular area, called aisle or lane, similarity to the longitudinally extending spaces that make up the places of worship such as churches and cathedrals. The combination of multiple aisles determines an arsenal, more or less extensive, depending on the military needs and/or economic port area.

The configuration of the aisle is defined by the scanning of a series of piers or pilasters that develop in longitude, so as to contain one or more boats at the same time in the same aisle. The rows of piers that were created were in arranged in parallel, so that each row was common to the two adjacent aisles, except for the first and the last one that could predict the blind perimeter outer walls for defensive reasons, creating precisely a unitary and compact complex. The interior space, instead, it appeared diaphanous thanks to the succession of pillars, allowing both physical and visual communication between the various aisles and also an optimum room ventilation. The aisles of the arsenals have a width, which varies from 8 to 10 $\mathrm{m}$ or so and can reach up to $100 \mathrm{~m}$ in length [5].

Built up outside of the wall fence with respect to the core of the city, the arsenals occupy large surfaces, and depending on their development, can be distinguished as follows (see Table 1): 
- Arsenals perpendicular to the coastline, divided in their turn into:

- Built on the arenile;

- Built in contact with water;

- Arsenals on wet dock (natural or artificial).

The first group is defined by those arsenals whose aisles see their longitudinal direction perpendicular to the coastline, or inland waterway or sea (as in the case of Seville and Barcelona, respectively). It is a setting that allows entry and exit of boats, taking advantage of the natural slope of the coast. Usually, the ships that did not require major maintenance works were halted near the shore and still maintained direct contact with yards, without entering into them. In other cases, the water lick directly the arsenal structure, allowing easy and comfortable manoeuvring to boats, eliminating the huge effort to tow the hulls in the transition zone between water and yard. The arsenal of Amalfi according to some hypotheses intended to have three aisles, which stretched towards the coast with the façade in direct contact with the water [6], unfortunately has not survived the entire structure, but only the back part. This configuration, however, is still noticeable in the arsenals of Alanya in Turkey [7], where it is evident penetration in the water of the foundations on which rest the façade arches and the direct contact between the aisles with the sea.

The arsenals belonging to the second group, on the contrary, elude direct contact with the coast for defensive reasons. In Pisa [8] or Venice, in fact, the shipyards are real productive neighbourhoods that possess their own wall fence. Wide arches are the doors through the ships pass without masts, accessing a large pool of water, called dock, around the naves are developed. The docks can arise out of natural bays, where there were primitive ports, or presenting engineering works in order to own shipbuilding facilities more and more advanced and sophisticated.

\section{ELEMENTS AND TECHNOLOGICAL SYSTEMS OF ARSENALS}

The typical technological system of arsenals is mainly constituted by a structures that ensures a vertical development, formed by walls marked by arched openings, on which rests a cover system (unique ceiling), generally a double pitch, which can be formed by beams wooden or stone vaulted structures. The essential elements of those structures are piers, flowing directly from foundations, arcs of connection, different depending on the development in the longitudinal and transverse direction; on the arches, there is the roof pitches, more or less sloping (Fig. 7).

\subsection{Foundations}

The transmission of loads to the ground of shipbuilding facilities take place, generally, through foundations that are realized by wooden piles into the sandy ground.

There is limited information about the foundation systems of the arsenals; however, some pieces of information are available from the case of the arsenals of Seville, on which a detailed study of the foundations has been conducted. There has been a continuous foundation, having a size of $1.30 \mathrm{~m}$ in height and 1.94 in width, which runs the full longitude [9]. Blocks or bricks, that form the piers of the real structure of the arsenals, were arranged in direct contact with the foundation.

\subsection{Piers}

The piers are made usually from natural stone blocks, square or irregular, and sometimes even by artificial stone elements such as solid brick. Have a section mostly square or rectangular, 

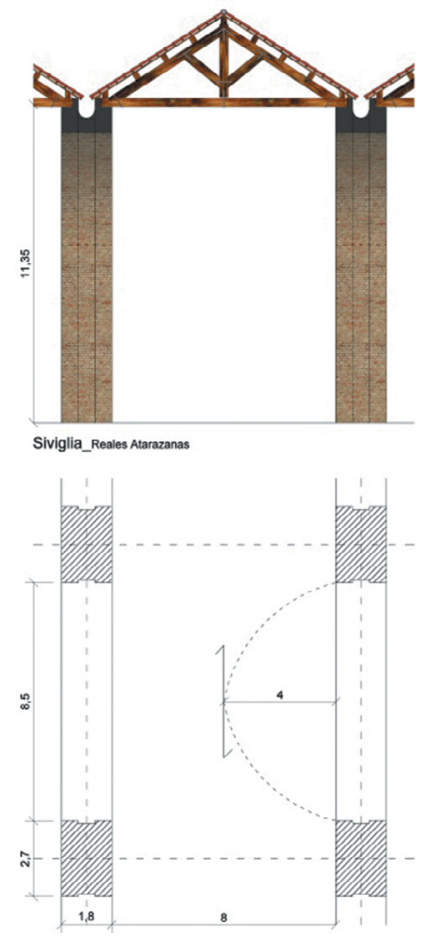
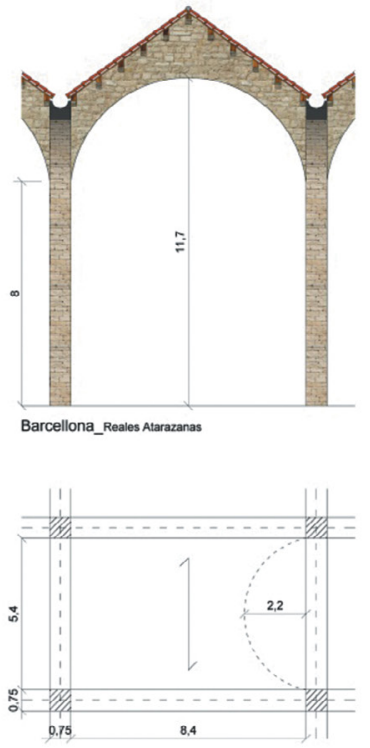
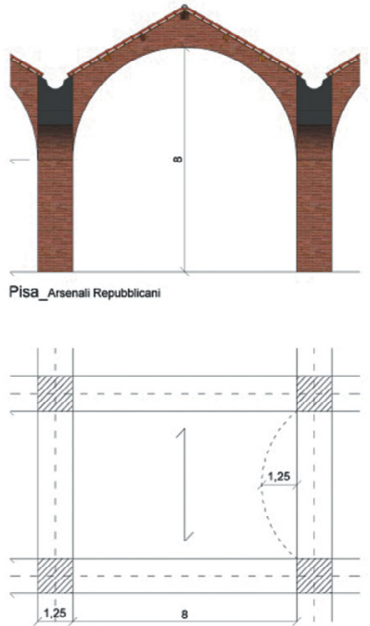

Figure 7: Typological comparison between the arsenals of Seville, Barcelona and Pisa.

circular few times and in rare cases in more articulated forms, for example to ' $\mathrm{H}$ ' shape [10] (this is the case of las Atarazanas of Seville). The most frequent ones are of rectangular shape; they have the larger side developed along the direction in which the light to be reached is wider. Depending on the mechanical characteristics of the materials used and the magnitude of the aisles, pillars may appear slim or stocky; however, they are seen connected together by arched systems in the longitudinal direction. Transverse union between the rows can be ensured through further arches or discharging always at the piers, creating solidarity between the parties, or leaving them independent so that the cover system is to put them in connection.

\subsection{Arches}

The type of arches is different depending on the height of the pillars and the span to be covered, with respect to the longitudinal or transverse direction of the aisle. If the pillars are sufficiently high and allow the passage of a vessel, they are often used round arches [11], on the other hand, when the height is not appropriate are adopted pointed arches that having a larger arrow, allow to reach satisfactory heights anyway. The arches between the aisles, which constitute essentially doors, are mostly segmental arches or pointed arch. Also the arches are constructed with the same materials of the piers to guarantee structural homogeneity. 


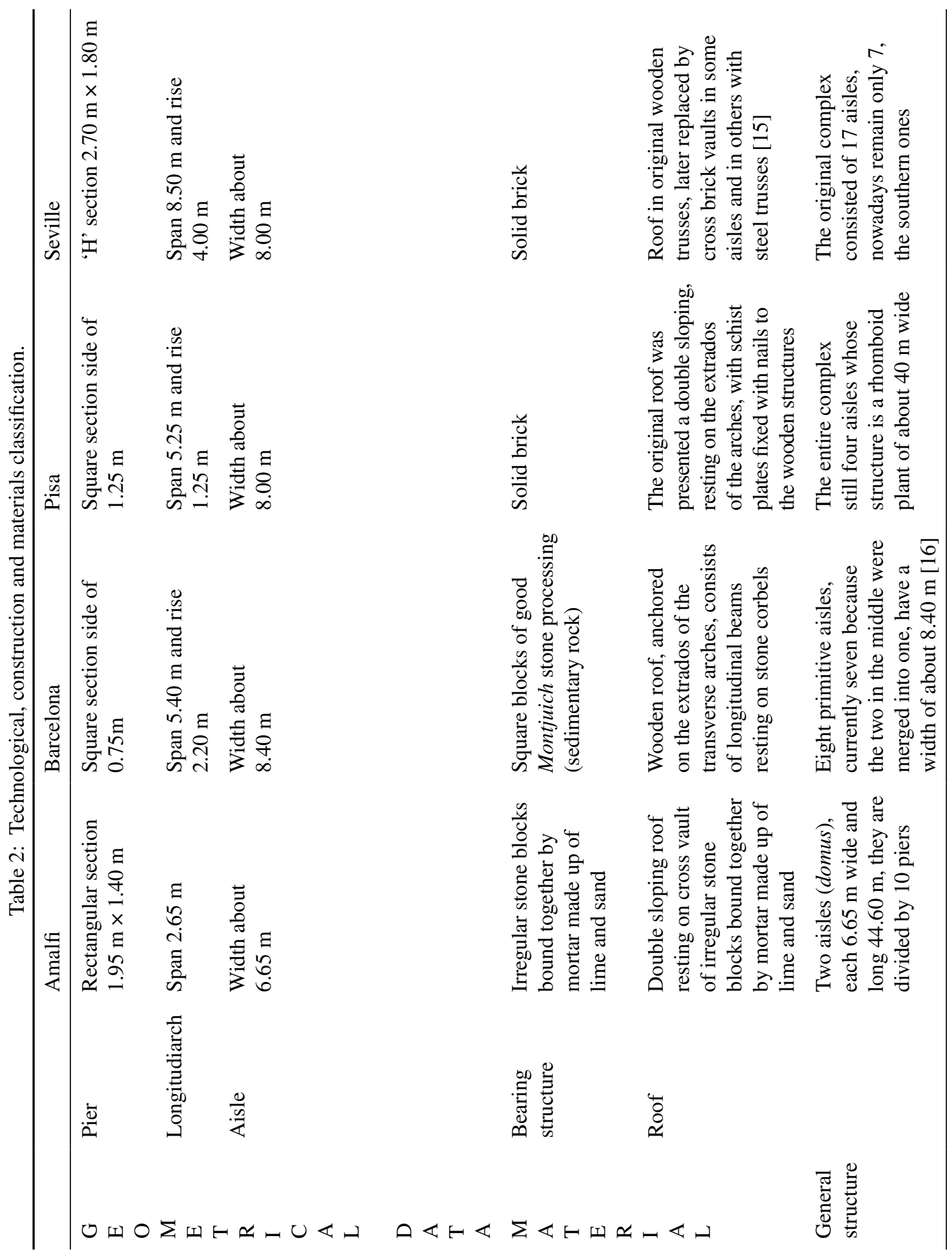




\subsection{Roofs}

The roof, which determines the volumetric configuration of the arsenals, is characterized by sloping, with more or less accentuated inclinations with respect to the geographical context, depending on whether it is maritime or river arsenals. Typically, for each aisle, there are two slopes that may be based essentially on three distinct technological systems: (a) on a wooden truss, (b) on the extrados of the vaulted structures or (c) on stone vault (even if present, are solutions have used in post-medieval times).

The first typology is used when the longitudinal walls rows, constituting the aisles, are independent of each other. This solution reproduces the traditional techniques used in the classical arsenals; a transverse ceiling joist on which fit together two oblique rafters, may provide a second order of wooden joists to which anchor the roof covering defined by tiles or stone slabs. Because the lights are to be covered more or less considerable, the trusses are formed by more articulated systems, with junction elements and fitting. The wooden horizontal element of the truss, the ceiling joist, can be placed directly on the walls rows, or with the terminal element incorporated in the masonry.

In the second typology, in the presence of transverse arches, with respect to the direction of the aisles, the roof rests directly on the arches. On the extrados of the arches, in fact, there are more stone elements, by such shaping of the wall at two slopes on which to place the main beams of the roof structure [12] (is the case of las Atarazanas of Barcelona).

The last typology is an evolution of the roofing system, mainly used to solve problems relating to the deterioration of the wood. As the arsenals are next to the considerable areas in relation with the water factor, and therefore in environments at high salt concentrations, the use of wood involves frequent maintenances. The problem is solved with the replacement of wooden trusses with vault also formed from the same material (stone elements) of the vertical structure. Is the case of Seville Hispanic-Muslims arsenals [13] or those Amalfi Angevin [14].

In any case, the system for disposal of rainwater is solved by means of a canal formed in correspondence of each row wall, in which is generated the area of valley roof between the pitches of the two adjacent aisles. The canal can end with a projecting element in the façade (the Gargoyle) that ensures the drainage of waters, or with an element for the channelling of water (Table 2).

\section{CONCLUSIONS}

Regardless of the geographical context, from building materials and the traditional building techniques, in the Mediterranean basin, the naval arsenals (built in the Middle Ages) repeat a similar typological scheme. Buildings from purely industrial character, the arsenals are presented free of decorative elements; indeed they are characterized by their clear and simple structure that defines impressive spatiality such those of monumental majestic places of contemporary worship.

Each arsenal, even in its particularity, shows spaces that predominates the development in length and are marked by pillars joined by arches. The powerful intrinsic formal structure of these architectures has created places from specimen prospects, places that paradoxically seem to possess a contemporary conception of space, pure spaces, anonymous and timeless. This is the characteristic that has allowed the continued existence of these buildings until today.

Because of the various transformations over the centuries, however, these facilities today are diversified and altered from their original condition, both changes that have affected the real structure and on those related to the surrounding context. 
Many arsenals have seen the loss of some aisles, the termination of their principal function, addition or subtraction of parts, and therefore does not show more in their integrity.

They constitute undoubtedly architectures capable of evoking the character of the places in which they arise and therefore deserve special attention, which must aim for their preservation and enhancement, to continue to perpetuate the ancient traditions of all those productive activities related to the art of navigation and not only.

\section{REFERENCES}

[1] Colletta, T., Arsenali navali marittimi e Musei delle città portuali mediterranee, TRIA, Rivista internazionale semestrale di cultura urbanistica, ${ }^{\circ}$ 46, 08/05/2008, pp. 135.

[2] Entry ARSENALE in Enciclopedia Sapere.it, De Agostini Editore 2012, available at http://www.sapere.it/sapere.html (accessed 10 December 2016).

[3] Entry ARSENALE in Enciclopedia Italiana Treccani, available at http://www.treccani.it (accessed 10 December 2016).

[4] Etymology of the word ARSENALE in Wikitecnica, available at http://www.wikitecnica.com (accessed 10 December 2016).

[5] In th geometric survey de las Atarazanas in Seville, reported in Barrionuevo, A. \& Molino, J., La Arquitectura de las Atarazanas. Permanencia y transformación, Recuperando las Atarazanas/Un monumento para la Cultura, Sevilla: 1999, pp. 11-34, the aisles are thus described: Las vastas proporciones de las diecisiete naves, de $100 \mathrm{~m}$ de largo y $12 \mathrm{~m}$ de altura $[\ldots]$ (The vast proportions of seventeen naves, $100 \mathrm{~m}$ long and $12 \mathrm{~m}$ high).

[6] Gargano, G., 'Arsenali e scaria di Amalfi nel contesto del Meridione medievale', in Ricoveri per navi militari nei porti del Mediterraneo antico e medievale: atti del Workshop, Ravello, 4-5 novembre 2005, EDIPUGLIA, Bari, 2010.

[7] Garcia Domingo, E., 'Arsenales históricos en el Mediterráneo', Portus N¹2, pp. 6469. Online magazine.

[8] Garzella, G., L'arsenale medievale di Pisa: primi sondaggi sulle fonti scritte, in Arsenali e città nell'Occidente europeo, pp. 51-61, 1987.

[9] Barrios Padura, A., Estudio de las cimentaciones de edificios históricos en la provincia de Sevilla: Siglo XII al XVI. Universidad de Sevilla, Departamento de Construcciones Arquitectónicas I, Sevilla, 2001.

[10] Barrionuevo, A. \& Molino, J., La Arquitectura de las Atarazanas. Permanencia y transformación, Recuperando las Atarazanas/Un monumento para la Cultura, Sevilla: 1999, pp. 11-34.

[11] This is the case of the arsenals of Barcelona where the tall and slender piers are united, transversely with respect to the aisle by round arches. Torres Balbás, L., Atarazanas hispanomusulmanas. Al-Andalus, XI, pp. 175-209, 1946.

[12] Torres Balbás, L., Naves cubiertas con armadura de madera sobre arcos perpiaños a partir del siglo XIII, Archivo español de arte, Tomo 33, No 129, pp. 19-44, 1960.

[13] Amores Carredano, F. \& Quiròs Esteban, C.A., Las Atarazanas: el tiempo y los usos, Recuperando las Atarazanas/Un monumento para la Cultura, Sevilla, pp. 35-56, 1999.

[14] Gargano, G., 'Arsenali e scaria di Amalfi nel contesto del Meridione medievale', in Ricoveri per navi militari nei porti del Mediterraneo antico e medievale: atti del Workshop, Ravello, 4-5 novembre 2005, Edipuglia, Bari, 2010.

[15] Debenedictis, D. \& Lallone, D., Evolution of the historical use and degradation of the Reales Atarazanas of Seville (XIII-XX century), Le Vie dei Mercanti, XIV International Forum, June 2016.

[16] Rieira I Melis, A., 'Las Atarazanas Reales de Barcelona', Catalònia, Num. 29, 1992. 